\title{
Annual net balance of North Cascade glaciers, 1984-94
}

\author{
Mauri S. Pelto \\ North Cascade Glacier Climale Project, Nichols College, Dudley, Massachusetts 01571, U.S.A.
}

\begin{abstract}
Annual net balance on eight North Cascade glaciers during the 198494 period has been determined by measurement of total mass loss from firn and ice melt and, of residual snow depth at the end of the summer season. Overall spatial density of measurement points is 200 points $\mathrm{km}^{2}$. Mean annual balance of North Cascade glaciers from 1984 to 1994 has been $-0.38 \mathrm{~m} \mathrm{a}^{-1}$. The resulting $4.2 \mathrm{~m}$ loss in water-equivalent thickness is significant, since North Cascade glaciers have an average thickness of $30-50 \mathrm{~m}$.

Cross-correlation of annual net balance for eight glaciers ranges from 0.83 to 0.97 . This indicates the mass balances of the eight glaciers have been responding similarly to climate conditions despite their range of topographic and geographic characteristics. Annual net balance of individual glaciers was correlated with climate records. The highest ablation-season correlation coefficient is mean May-August temperature, ranging from 0.63 to 0.84 . The highest accumulation-season correlation coefficient is total accumulation-season precipitation, ranging from 0.35 to 0.59 .
\end{abstract}

\section{MASS-BALANCE MEASUREMENT}

The North Cascades mountains are host to approximately 725 glaciers (Fig. 1) (Post and others, 1971; Pelto, 1993). The North Cascade Glacier Climate Project (NCGCP) was founded to identify the response of North Cascade glaciers to regional climate change. Ebbesmeyer and others (1991) noted the broad impact of a regional climate change occurring in 1976, identifying a significant shift in 40 environmental factors that are sensitive to climate. Glacier response to alpine weather patterns and climate is complicated by local effects. Thus, to understand the causes of and nature of changes in glacier mass balance, it was necessary to monitor a significant number of glaciers. Since 1984, the North Cascade Glacier Climate Project has monitored annual net balance on at least eight North Cascade glaciers (Pelto, 1988, 1993). To monitor this number of glaciers in the United States is not feasible financially or logistically using standard massbalance methods. A modified stratigraphic method based on an observable summer surface is used to reduce logistical costs.

Annual balance is the difference between annual snow accumulation and snow-firn ice melt (ablation). Massbalance measurements are made on the same date each year in August and again in late September close to the end of the ablation season. The late September date is considered the end of the hydrologic year for that glacier. Any mass-balance changes occurring before the actual accumulation season begins is a measured mass loss or gain for the next hydrologic year. Annual ice and firn ablation (firn and ice net balance: Mayo and others, 1972 is determined using ablation stakes drilled into the glacier surface and simultaneously checked on the same date in late September. Residual snow accumulation (final late snow balance: Mayo and others, 1972) at the end of the ablation season is determined using probing and crevasse stratigraphy on the same date as ablation measurements are completed. The methods used are patterned after mass-balance studies on Lemon Creek Glacier, Alaska, and Blue Glacier, Washington Heusser and Marcus, 1964; LaChapelle, 1965; Armstrong, 1989). The only difference between the methods used on Blue Glacier LaChapelle, 1965; Armstrong, 1989) and in this study are: (1) snow density is not measured; (2) an order of magnitude higher measurement density is used.

Only accumulation measurements are made above the snow line in the accumulation zone. In the accumulation zone, annual accumulation-layer thickness is determined using crevasse stratigraphy and probing. Measurements are made in August and again in late September. The August measurements are made to determine snowmelt run-off for the late summer period and are not used in the final annual balance assessment. The average density of measurements utilized in this study is 290 points km ${ }^{2}$, while the average density of measurements used in assessing the mass balance in the accumulation zone of other Canadian, Norwegian, Swiss and United States glaciers is 33 points $\mathrm{km}^{-2}$ Pytte, 1969; Meier, and others, 1971) (Table 1). This higher density is achieved by focusing on time-efficient measurement methods.

The accumulation-layer thickness is measured at each point to the nearest $0.01 \mathrm{~m}$. Crevasse stratigraphy measurements are conducted only in vertically walled crevasses with distinguishable dirt bands. Crevasses lacking vertical walls yield inaccurate depth measurements. In the North Cascades the ablation surface of the previous year is always marked by a $2-5 \mathrm{~cm}$ thick band of dirty firn or glacier ice. The depth to the top of this dirty band is measured at several points on each crevasse wall 


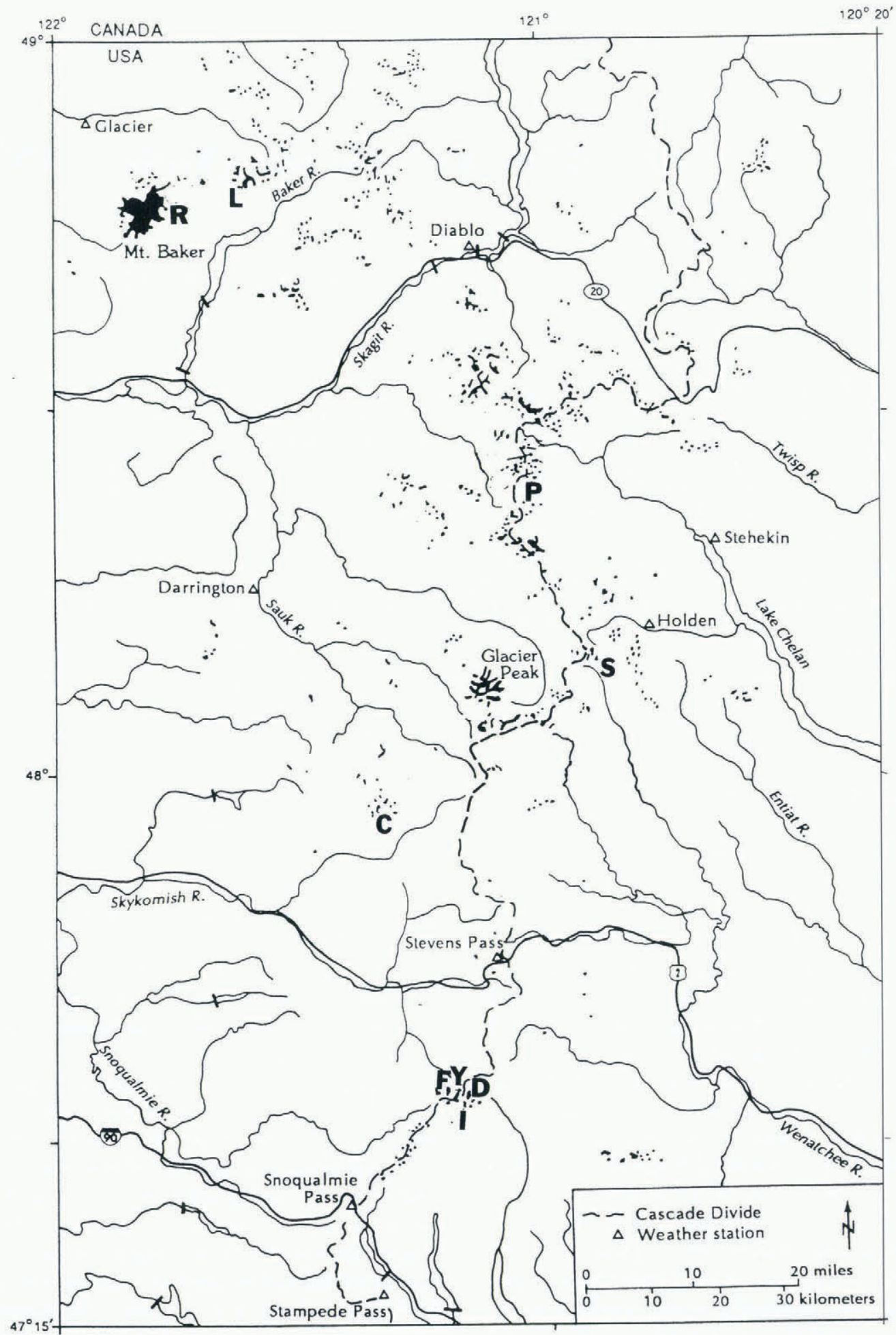

Fig. 1. Location of the nine glaciers on which annual balance measurements have been made by. NCGCP from 1984 to 1993. C, Columbia; D, Daniels; F, Foss; I, Ice Worm; L, Lower Curtis; P. Yawning; R, Rainbow; S, Spider; Y, Lynch.

within a distance of several meters. The average thickness of the several points is taken to be the accumulation-layer thickness at that location.

We completed more than 100 snow pits from 1984 to 1986, the range in mean accumulation-layer density observed was $0.58-0.63 \mathrm{Mg} \mathrm{m}^{3}$. This narrow range indicates that late in the ablation season the density of snowpack on North Cascade glaciers is uniform and need not be measured to determine mass balance. For this reason, snow pits are no longer utilized. The lack of density variation has been observed in the two other mass-balance programs in Washington on Blue Glacier and South Cascade Glacier (Meier and Tangborn, 1965; Armstrong, 1989). Of equal importance is that the range of density variation is of the same order as the densitymeasurement error, determined through repeat measurements. Since North Cascade glaciers rarely have ice lenses (an indicator of little internal accumulation), probing is an accurate method of measuring accumulation-layer thickness. The lack of ice lenses is also crucial to having a constant snow density. The probe is driven through the snowpack until the previous ablation surface is reached; 
Table 1. The number of measurement siles used and their density in $\mathrm{km}^{2}$ in mass-balance studies on selected glaciers: in Swizerland (A) (Aellen, 1980), by the United States Geological Survey (U) (Meier and olhers, 1971), by the . Norges Vassdrags-Elektrissen (N) (Pytte, 1969) and by the North Cascade Glacier Climate Project (P)

\begin{tabular}{|c|c|c|c|c|c|}
\hline \multirow[t]{2}{*}{ Glacier } & \multicolumn{2}{|c|}{ Ablation area } & \multicolumn{2}{|c|}{ Accumulation area } & \multirow[t]{2}{*}{ Source } \\
\hline & Siles & Density & Sites & Densily & \\
\hline Limmern & 12 & 8 & 17 & 2 & A \\
\hline Silveretta & 18 & 10 & 21 & 13 & A \\
\hline Greis & 27 & 9 & 28 & 9 & A \\
\hline Gulkana & 20 & 3 & 68 & 6 & $\mathrm{U}$ \\
\hline South Cascade & 20 & 17 & 81 & 50 & $\mathrm{U}$ \\
\hline Wolverine & 15 & 1 & 105 & 6 & $\mathrm{U}$ \\
\hline Alfotbreen & 5 & 4 & 126 & 35 & $\mathrm{~N}$ \\
\hline Austre Memurubre & 8 & 3 & 316 & 52 & $\mathrm{~N}$ \\
\hline Grasubreen & 9 & 8 & 125 & 50 & $\mathrm{~N}$ \\
\hline Hellstugubreen & 13 & 7 & 216 & 144 & $\mathrm{~N}$ \\
\hline Nigardsbreen & 10 & 4 & 237 & 5 & $\mathrm{~N}$ \\
\hline Vestre Memurubre & 6 & 4 & 88 & 10 & $\mathrm{~N}$ \\
\hline Columbia & 3 & 10 & 165 & 250 & $\mathrm{P}$ \\
\hline Daniels & 4 & 12 & 115 & 280 & $\mathrm{P}$ \\
\hline Foss & 3 & 15 & 110 & 240 & $\mathrm{P}$ \\
\hline Lower Curtis & 3 & 10 & 185 & 280 & $\mathrm{P}$ \\
\hline Lynch & 3 & 10 & 125 & 250 & $\mathrm{P}$ \\
\hline Rainbow & 3 & 6 & 200 & 180 & $\mathrm{P}$ \\
\hline
\end{tabular}

this surface of glacier ice or dirty hard firn cannot be penetrated. The probing instrument is a $1 / 2 \mathrm{in}[1.27 \mathrm{~cm}]$ thick type L copper tube which is driven through the snowpack using a $1 \mathrm{~kg}$ weight.

The accuracy of crevasse stratigraphy and probing measurements is cross-checked by comparing for consistency. On each glacier, at least $25 \%$ of the accumulation area is a zone of overlap where both probing and crevasse stratigraphy are used. This cross-checking identifies measurement points that either represent an ice lens and not the previous summer surface in the case of probing or areas where crevasses do not yield representative accumulation depth in the case of crevasse stratigraphy.

The standard deviation in snow depth obtained in cross-checking and duplicate measurements is smallest for crevasse stratigraphy, $0.02 \mathrm{~m}$, and $0.03 \mathrm{~m}$ for probing. The narrow range of deviation in vertically walled crevasses indicates that they do yield consistent and representative accumulation depths late in the summer. After a decade of predominantly negative mass balance, the number of crevasses that are sufficiently open to complete measurements has declined significantly.

To ensure that mass-balance measurements are consistent from year to year, measurements are made at a spatially fixed network of points using the same methods on the same date each year. The network is fixed spatially with respect to the surrounding bedrock walls. A typical measurement network is shown in Figure 2. Each measurement network covers a glacier's entire accumulation zone with a reasonably consistent density of measurements. Because all of the sites are accessed by backpacking, it has not been a problem to reach each glacier at the right date.

Mass-balance measurements are in water equivalent.
The product of the accumulation-layer thickness and density of the snowpack $\left.0.60 \mathrm{Mg} \mathrm{m}^{3}\right)$ yields the water equivalent. Errors in depth measurement are less than $\pm 0.05 \mathrm{~m}$, and $\pm 0.02-0.03 \mathrm{Mgm}^{3}$ is the error due to density variation. The resulting error in annual assessment for the accumulation zone ranges from \pm 0.10 to $\pm 0.15 \mathrm{~m}$.

Below the snow line, ablation stakes emplaced in a triangular pattern are used to determine annual ablation. An ablation triangle consists of three stakes driven or drilled into the ice at $3 \mathrm{~m}$ spacing, forming an equilateral triangle. Three to four triangles are emplaced on each glacier. Ablation stakes are white wooden poles $3.3 \mathrm{~m}$ long. This length was chosen as longer stakes are too cumbersome to transport and emplace, and shorter stakes tend to melt out. Ablation measurements are made at nine points on the triangle periphery from a cross bar resting upon two of the ablation stakes to the firn or ice surface. Measurements are made in late July and early August, recording the ablation during the first 3 months of the ablation season. After re-drilling if necessary in August, ablation measurements are repeated in late September at the designated conclusion of the hydrologic year.

Ablation triangles are placed in a sequence from regions that first lose their snow cover to regions where snow cover persists for a significant part of the ablation season. Each ablation triangle is then representative of ablation for other parts of the glacier that lose their snowpack simultaneously. Ablation variation over the entire ablation season at the different points on the periphery of a single ablation triangle are insignificant. Thus, individual ablation stakes will be used in future years. If a stake melts out, it is not utilized in assessing ablation. Stake melt-out has been infrequent; two stakes melted out in 1987 on Lower Curtis Glacier and in 1992 


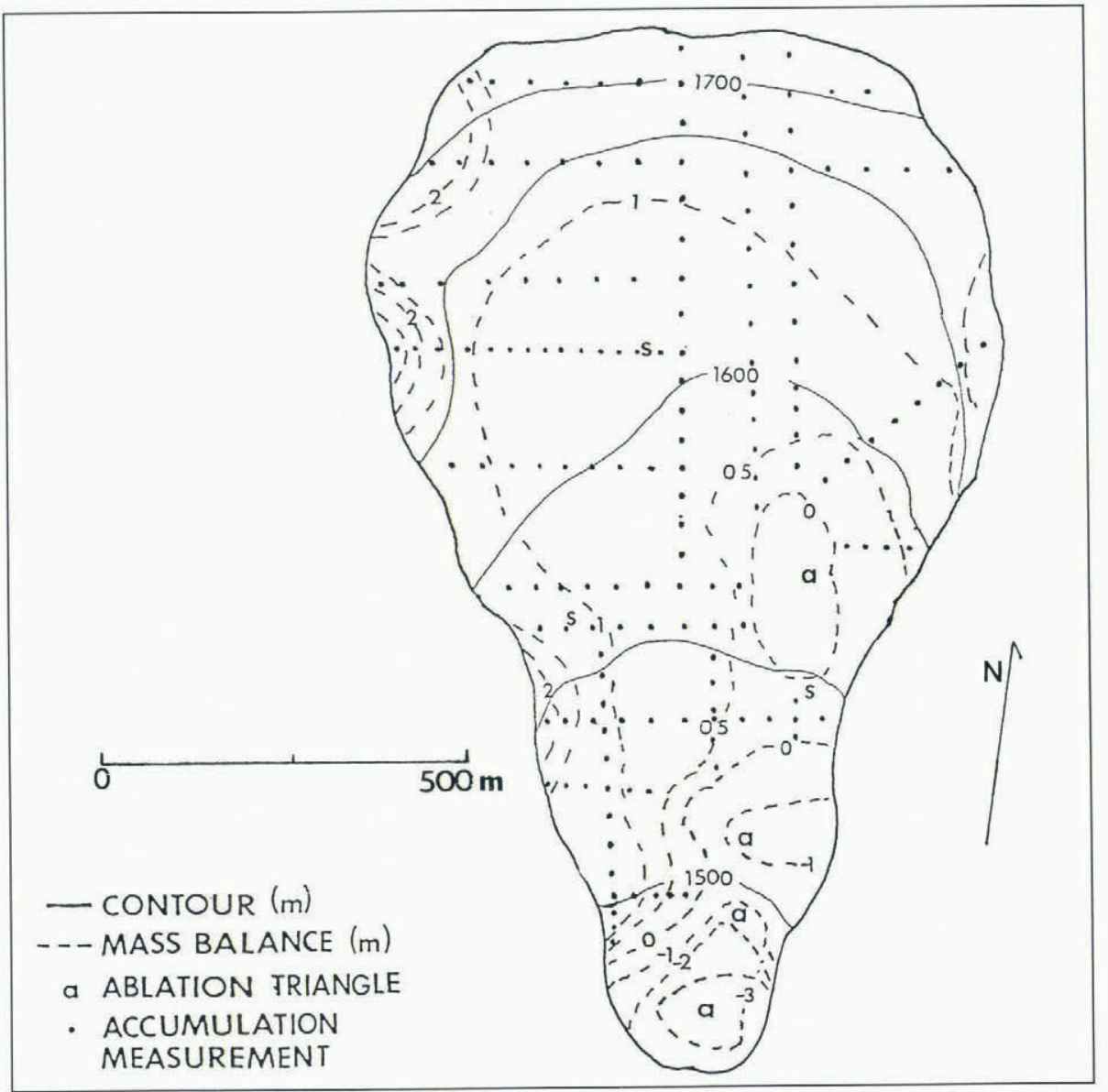

Fig. 2. Mass-balance measurement network on Columbia Glacier in 1991. Measurements are made at each of these points at the same lime each year. Annual balance contours are then constructed.

on Rainbow Glacier.

The error in annual ablation measurements is estimaled al $\pm 0.25 \mathrm{~m}$, due to ice-density variations, low sampling density and stake settling. This estimate is based on the standard deviation in ablation along $50 \mathrm{~m}$ long transects with ablation stakes placed $5 \mathrm{~m}$ apart. Two of these transects were emplaced on Columbia Glacier in 1987 and on Rainbow Glacier in 1991. There are at least three ablation-measurement sites on each glacier. The sampling density is low at 6-20 points $\mathrm{km}^{2}$, but comparable to the mean density of $3-17$ points $\mathrm{km}^{-2}$ used by the USGS and NVE (Table 1).

A mass-balance map for the entire glacier is then compiled for each glacier. The mass balance for the entire glacier is calculated by summation of the product of glacier area within each $0.10 \mathrm{~m}$ mass-balance contour and the net balance of that interval. The error in massbalance calculation for the entire glacier is $\pm 0.17-0.22 \mathrm{~m}$. The annual balance from 1984 to 1993 for the nine North Cascade glaciers and in 1994 for eight glaciers is shown in Table 2. Spider Glacier will no longer be monitored; it could not be reached in 1994 because of forest fires in the

Table 2. The annual balance of . North Cascade glaciers from direct measurements (in meters of water equivalent)

\begin{tabular}{lccccccccccc}
\hline Glacier & \multirow{2}{*}{1984} & 1985 & 1986 & 1987 & 1988 & 1989 & 1990 & 1991 & 1992 & 1993 & 1994 \\
\hline Columbia & +0.21 & -0.31 & -0.20 & -0.63 & +0.14 & -0.09 & -0.06 & +0.38 & -1.85 & -0.90 & -0.96 \\
Danicls & +0.11 & -0.51 & -0.36 & -0.87 & -0.15 & -0.37 & -0.68 & -0.07 & -1.70 & -0.83 & -0.35 \\
Foss & +0.51 & -0.69 & +0.12 & -0.38 & +0.23 & +0.09 & -0.27 & +0.30 & -1.92 & -0.73 & -0.68 \\
Ice Worm & +0.86 & -0.75 & -0.45 & -1.39 & -0.24 & -0.67 & -0.92 & +0.63 & -2.23 & -1.02 & -1.23 \\
L. Curtis & +0.39 & -0.16 & -0.22 & -0.56 & -0.06 & -0.29 & -0.51 & +0.04 & -1.76 & -0.48 & -0.55 \\
Lynch & +0.33 & -0.22 & -0.07 & -0.30 & +0.17 & +0.03 & -0.12 & +0.36 & -1.38 & -0.62 & -0.40 \\
Rainbow & +0.58 & +0.04 & +0.20 & -0.26 & +0.43 & -0.24 & -0.46 & +0.44 & -1.65 & -0.80 & -0.78 \\
Spider & +1.12 & -0.63 & +0.30 & -1.15 & +0.73 & -0.15 & -0.96 & +1.10 & -0.67 & -0.40 & -0.62 \\
Yawning & +0.09 & -0.23 & -0.14 & -0.47 & -0.06 & -0.19 & -0.32 & +0.23 & -2.06 & -0.66 & -0.62 \\
Mean & +0.39 & -0.35 & -0.14 & -0.61 & +0.06 & -0.22 & -0.42 & +0.29 & -1.81 & -0.75 & -0.69 \\
\hline
\end{tabular}


Table 3. Cross-correlation table of anmual net balance for eight. North Cascade glaciers for the 198493 period

\begin{tabular}{lcccccccc}
\hline & Col. & Dan. & Foss & IcW & LoC & Lyn. & Rbw. & Ywg. \\
\hline Columbia & 1.00 & 0.96 & 0.95 & 0.88 & 0.94 & 0.94 & 0.90 & 0.97 \\
Daniels & 0.96 & 1.00 & 0.95 & 0.94 & 0.98 & 0.93 & 0.95 & 0.94 \\
Foss & 0.95 & 0.95 & 1.00 & 0.87 & 0.92 & 0.92 & 0.90 & 0.94 \\
Ice Worm & 0.88 & 0.94 & 0.87 & 1.00 & 0.91 & 0.83 & 0.86 & 0.85 \\
Lower Curtis & 0.94 & 0.98 & 0.92 & 0.91 & 1.00 & 0.90 & 0.95 & 0.96 \\
Lynch & 0.94 & 0.93 & 0.92 & 0.83 & 0.90 & 1.00 & 0.94 & 0.90 \\
Rainbow & 0.90 & 0.95 & 0.90 & 0.86 & 0.95 & 0.94 & 1.00 & 0.91 \\
Yawning & 0.97 & 0.94 & 0.94 & 0.85 & 0.96 & 0.90 & 0.91 & 1.00 \\
\hline
\end{tabular}

watershed. The mean annual balance of $-0.38 \mathrm{~m} \mathrm{a}^{1}$ for the eight glaciers during the 198494 period is a mean loss of $3.5-5.0 \mathrm{~m}$ of glacier thickness during the last 11 years. This is a significant amount given the thin nature of North Cascade glaciers estimated to range from $3060 \mathrm{~m}$ (Post and others, 1971).

\section{CROSS-CORRELATION OF NET ANNUAL BALANCE}

Table 3 contains the cross-correlation of annual balance for the eight North Cascade glaciers. The high crosscorrelations $(0.83-0.97)$ indicate the similarity of each glacier's annual balance response to the annual climate conditions. Figure 3 displays the annual balance of the eight North Cascade glaciers observed by NCGCP from 1984 to 1994. The trend from year to year is quite consistent, illustrating the high cross-correlations. The actual range in annual balance between the glaciers for any given year is significant (Fig. 3 ).

The individual glaciers were selected to represent a range of geographic and topographic characteristics.
Geographic characteristics of each glacier are given in Table 4.

The moderate range of variation in annual balance makes distinguishing which geographic characteristics are most important in determining climate sensitivity difficult. This tendency for small alpine glaciers in the Pacific Northwest to have different mass-balance histories, yet high cross-correlation coefficients, was previously noted by Letréguilly and Reynaud (1989). Letréguilly and Reynaud (1989) compared the mean annual balance histories from 1956 to 1985 of Blue Glacier, Olympic Mountains $\left(+0.35 \mathrm{ma}^{1}\right)$ and South Cascade Glacier, North Cascades $\left(-0.45 \mathrm{ma}^{1}\right)$, which were very different. However, their sensivity to specific climate conditions, as indicated by a cross-correlation coefficient of 0.69 , was quite high for two glaciers in different, though adjacent, mountain ranges.

Pelto (1988), in examining the first several years of mass-balance data, postulated that the variation in annual balance between glaciers is due to their different geographic characteristics. The high cross-correlation of annual balance for each glacier suggests that the geographic characteristics are of secondary importance to

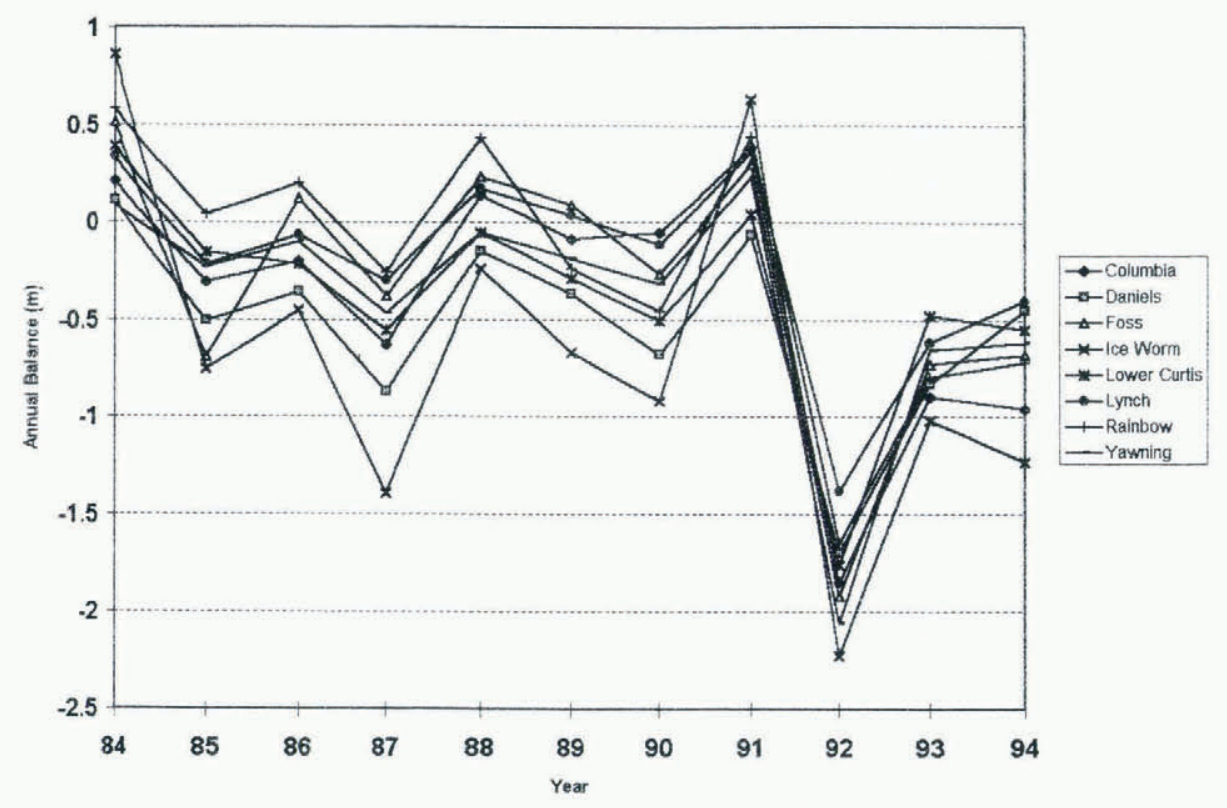

Fig. 3. The annual balance of eight North Cascade glaciers. Note that there is a significant range in annual balance between the glaciers and that the pattern of change from year to year is similar for all of the glaciers. 
Table 4. The geographic characleristics of eight glaciers where annual balance has been monitored annually since 1984 and will continue to be monitored. Accumulation sources: wind drifting (WD), avalanche accumulation ( $A V)$, direct snowfall (DS)

Glacier Orientation Accumulation sources Distance from Divide Elevation range

\begin{tabular}{lcccc}
\hline Columbia & SSE & DS, WD, AV & $15 \mathrm{~km}$ west & $1750-1450$ \\
Daniels & $\mathrm{E}$ & DS, WD & 1 km east & $2230-1970$ \\
Foss & NE & DS & At Divide & $2100-1840$ \\
Ice Worm & SE & DS, AV & $1 \mathrm{~km}$ east & $2100-1900$ \\
Lower Curtis & $\mathrm{S}$ & DS, WD & $55 \mathrm{~km}$ west & $1850-1460$ \\
Lynch & $\mathrm{N}$ & DS, WD & At Divide & $2200-1950$ \\
Rainbow & ENE & DS, AV & $70 \mathrm{~km}$ west & $2040-1310$ \\
Yawning & $\mathrm{N}$ & DS & At Divide & $2100-1880$ \\
\end{tabular}

actual climate conditions but does not suggest that geographic characteristics are unimportant. The mean annual balance differences between glaciers do reflect important differences that are probably the result of changing geographic characteristics. The annual balance record is insufficient to assess fully this hypothesis yet.

\section{NET ANNUAL BALANGE GLIMATE CORRELATION}

A comparison of the long-term and short-term mean for monthly precipitation and temperature from the eight NOAA State of Washington Division 5 Weather Stations Cascade Mountains) illustrates three important climate changes in the North Cascades for the 198494 period. (1) Mean ablation-season temperature has been $1.1^{\circ} \mathrm{C}$ above the long-term mean $(1950-80)$. (2) Winter precipitation has been $11 \%$ below the long-term mean. (3) Mean April-June temperature has been $1.3 \mathrm{C}$ above the longterm mean. All three of these changes lead to more negative balances and have been the cause of the rapid glacial retreat that has occurred in the North Cascades during the last 5-7 years (Pelto, 1993).

The four primary climatic variables affecting North Cascade glaciers are ablation-season temperature, accumulation-season precipitation, summer cloud cover and May and October freezing levels (Tangborn, 1980; Pelto, 1988). Since summer cloud cover is not monitored in the North Cascade region, this parameter cannot be examined. Porter (1977) and Tangborn (1980) demonstrated that summer cloud cover is highly correlated with summer temperature, is inherently included in the temperature record and is not an independent variable. Freezing-level elevations are incorporated by including only May and October precipitation occurring when Stevens Pass temperature is below $7^{\circ} \mathrm{C}$ as accumulationseason precipitation.

Comparison between net annual balance for each glacier and accumulation-season and ablation-season conditions at NOAA Washington State Division 5 weather stations is presented in Table 5. Four different measurement methods of accumulation-season precipitation (ppt.) are used: (1) October-March ppt., (2)
October April ppt., (3) November-March ppt., (4) all precipitation from October to May that falls when the temperature at Stevens Pass is below $7^{\circ} \mathrm{C}$. Precipitation data used is the monthly mean for Division 5 weather stations. Weather records from 11 individual weather stations were also correlated with annual balance but each vielded lower correlation coefficients than the Cascade Mountain Division record, probably due to the significant local changes in precipitation for many storm events.

The highest correlation coefficients were for measurement method 4 (all precipitation from October to May that falls when the temperature at Stevens Pass is below $7^{\circ} \mathrm{C}$ ) ranging from 0.36 to 0.59 . Only on Yawning Glacier was another method as accurate: method 1 October March ppt.) with an identical correlation coefficient. This demonstrates the robustness of method 4.

During the ablation season, four climate variables were used: (1) May-August mean temperature, (2) MaySeptember mean temperature, (3) June-August mean temperature, (4) June September mean temperature. Temperatures used were monthly means from Division 5 weather stations. Method 1 May-August mean temperature) proved to be the most accurate with correlation coefficients ranging from 0.63 to 0.84 . This was true on all but Lynch Glacier and Rainbow Glacier. Lynch Glacier and Rainbow Glacier have the least negative mean annual balance and highest mean accumulation-zone altitude of the eight glaciers. These two glaciers were more closely related to June-September temperature. Except for Lynch and Rainbow Glaciers, method 1 yielded correlation coefficients between 0.75 and 0.84 .

The correlation between annual net balance is higher for ablation-season temperature than for accumulationseason precipitation. This does not demonstrate that the glaciers are more sensitive to ablation-season conditions. It is more likely a result of temperature being a better measure of ablation than precipitation of actual accumulation.

\section{CONCLUSION}

The annual balance of North Cascade glaciers between 1984 and 1994 has been moderately negative at $-0.38 \mathrm{~m} \mathrm{a}^{-1}$. Crevassing on all nine glaciers where annual 
Table 5. Correlation coefficients between measured annual balance, and ablation-season temperature and accumulation-season lemperalure. Three different intervals during the ablation season are used: May-August (M-A), May-September (.M-S), June September (J-S). Accumulation-season precipitation includes all precipilation between 1 Oclober and 1 June (ASP) that falls when the temperature at Stevens Pass is below $5 \mathrm{C}$. October-April $(O-A)$ includes all precipitation during this period

\begin{tabular}{lccccc}
\hline \multirow{2}{*}{ Glacier } & \multicolumn{3}{c}{ Ablation-season lemperalure } & \multicolumn{2}{c}{ Accumulation } \\
& $\mathrm{M}-\mathrm{A}$ & $\mathrm{M}-\mathrm{S}$ & $\mathrm{J}-\mathrm{S}$ & $\mathrm{ASP}$ & $\mathrm{O}-\mathrm{A}$ \\
\hline Columbia & & & & \\
Daniels & -0.81 & -0.73 & -0.53 & 0.50 & 0.41 \\
Foss & -0.78 & -0.89 & -0.74 & 0.46 & 0.29 \\
Ice Worm & -0.79 & -0.70 & -0.60 & 0.50 & 0.40 \\
Lower Curtis & -0.75 & -0.86 & -0.71 & 0.59 & 0.44 \\
Lynch & -0.78 & -0.87 & -0.68 & 0.35 & 0.25 \\
Rainbow & -0.63 & -0.78 & -0.73 & 0.57 & 0.41 \\
Yawning & -0.64 & -0.82 & -0.68 & 0.39 & 0.22 \\
& -0.84 & -0.74 & -0.56 & 0.36 & 0.36 \\
\hline
\end{tabular}

balance measurements have been made has also diminished significantly. A loss of $4.2 \mathrm{~m}$ of ice thickness on glaciers with an estimated mean thickness of $3050 \mathrm{~m}$ (Post and others, 1971) is significant.

The result of negative annual balance has been glacier retreat. In 1985, of the 47 glaciers we observed 38 were retreating. In 1994, 46 of 47 glaciers observed were retreating (Pelto, 1993). Lewis Glacier with an area of $0.09 \mathrm{~km}^{2}$ was initially selected for annual mass-balance measurements. After completing measurements from 1984 to 1988, Lewis Glacier melted away in 1989 and 1990, leaving relict ice with an area of $0.03 \mathrm{~km}^{2}$ by the end of 1990. In 1992, David Glacier near Glacier Peak ceased to exist. In 1993, Milk Lake Glacier disappeared. Each of these three glaciers has low winter accumulation. Glaciers with geographic factors increasing mean net annual accumulation have had less negative annual balances and slower glacier-retreat rates (Pelto, 1993). During the 198494 period, glacier-retreat rates have increased substantially due to negative annual balances Pelto, 1993). The high negative annual balance of recent years combined with the small size of the glaciers will ensure a continued retreat for the next several years.

\section{ACKNOWLEDGEMENTS}

This project has received essential support from the Foundation for Glacier and Environmental Research, The manuscript was greatly improved by K. Reed, Washington, Division of Geology and Earth Resources, D. MacAyeal and two anonymous reviewers. Field assistants were K. Barcsay, Z. Barcsay, J. Brownlee, R. Campbell, M. Carver, J. Drumheller, A. Fitzpatrick, M. Gowan, J. Harper, C. Hedlund, M. Hylland, D. Kaplinski, D. Klinger, D. Knoll, B. Long, J. Maggiore, C. Mitchell, B. Prater, D. Sayegh, L. Scheper and J. Turner,

\section{REFERENCES}

Acllen, M. 1988. Die Gletschen der Schweizer Alpen 197980 und 1980/81. Les zariations des glaciers suisses 197980 el 1980 81. Zürich. Eidgenössische Technische Hochschule. Versuchsanstalt für Wasserbau, Hydrologic und Glaziologie. Gletscherkommission.

Armstrong, R.L. 1989. Mass balance history of Blue Glacier. Washington, U.S.A. In Oerlemans, J., ed, Gilacier flucluations and climatic change. Dordrecht, Kluwer Academic Publishers, 183192.

Ebbesmeyer, C.C., C. R. Cayan, D. R. McLain, F.H. Nichols, D. H. Peterson and K. T. Redmond. 1991. 1976 step in the Pacilic climate: forty environmental changes between 1968-1975 and 1977 1984. In Betancourt, J. I.. and V. Tharp, eds. Proceedings of the 7th . Lmmual Pacifie Climate (PACLIAM) Norkshop. 10 13 April 1990. Asilomar. California. California Department of Water Resources. Sacramento, 129-141. Interagency Ecological Studies Program Technical Report 26.

Heusser, C.J. and M. G. Marcus. 1964. Surface movement, hydrological change and equilibrium flow on Lemon Creek Glacier, Alaska. $J$. Glaciol., 537 , $61-75$.

LaChapelle, E. 1965. The mass budget of Blue Glacier. Washington. J Glaciol., $5+1$ ), 609-623.

Letréguilly, A. and L. Reynaud. 1989. Spatial patterns of mass-balance fluctuations of North American glaciers. f. Glaciol.. 35 120), 163-168.

Mayo. L. R.. M.F. Meier and W. V. Tangborn. 1972. A system to combine stratigraphic and annual mass-balance systems: a contribution to the International Hydrological Decade. F. Cilaciol.. 11 61 . 3-14.

Meier, M.F. and W. V. Tangborn. 196.5. Net budget and flow of South Cascade Glacier, Washington. J. Glaciol., 5 41), 547-566.

Meier, M.F., W. V. Tangborn, L. R. Mayo and A. Post. 1971. Combined ice and water balances of Gulkana and Wolverine Glaciers, Alaska, and South Cascade Glacier, Washington, 1965 and 1966 water years. U.S. Geol. Surv. Prof. Pap. 715-A.

Pelto, M.S. 1988. The annual balance of North Cascade glaciers. Washington, U.S.A., measured and predicted using an activity-index method. J. Glaciol., 34 117). 194199.

Pelto, M.S. 1993. Current behavior of glaciers in the North Cascades and effect on regional water supplies. Wash. Geal., 21 2 , 310.

Porter, S.C. 1977. Present and past glaciation threshold in the Cascade Range, Washington, U.S.A.: topographic and climatic controls and paleoclimatic implications. J. Glaciol., 18 78, $101-116$.

Post. A., D. Richardson, W. V. Tanghorn and F.L. Rosselot. 1971. Inventory of glaciers in the North Cascades, Washington. U.S. Geol. Surv. Prof. Pap. 705-1.

Pyute, R., ed. 1969. Glasiologiske undersökelser i Nonge 1968. Oslo, Norges Vassdrags-og Elektrisitetsvesen. Vassdragsdirektoratet. Rapport 5/69.

Tangborn. W. 1980. Two models for estimating climate glacier relationships in the North Cascades, Washington, U.S.A. \%. Glaciol., 2591 ). 321. 